\section{A matter of judgment}

David Spurgeon writes from Ottawa on a report covering Canada's problematic science-industry relationship

IN 1973, the Ministry of State for Science and Technology (MOSST) introduced a "Make-or-Buy" policy, the aim of which was to increase the proportion of government-funded research and development (R\&D) carried out under contract by industry as opposed to government laboratories. The government hoped to strengthen the innovative capacity of Canadian industry and to enhance its competitive position. The policy has not generally been regarded as a howling success, especially by industrialists. In the year following its introduction, in fact, the Cabinet found it necessary to expand the original policy to allow financing of unsolicited proposals for R\&D from the private sector.

A steady decline in support has generally been seen in the government's R\&D funding policies. A brief from the Royal Society of Canada to the Prime Minister said that, although it was generally recognised in 1969 that government support for industrial R\&D was already too small, it is now even smaller: in terms of the fraction of federal budgetary expenditures it had fallen by 1975 to $68 \%$ of the 1969 level.

Now a report has come from the MOSST* conveying the message that the Make-or-Buy Policy has in fact been rather successful, and that more of it is needed. The report is full of statistics supporting its argument, but its general tone appeared so contrary to what could be heard in non-government quarters that it left the impression of being a rather curious document.

A little investigation suggests why: the choice of statistics is highly selective, some say misleading. In fact it is questionable in some cases whether they show what they are purported to show. One table, for example, shows the increase since 1973-74 of missionoriented contracts awarded to industry by the Department of Supply and Services on behalf of the various government departments, the intent being to indicate that they have increased. Yet the table lumps together all contracts from government departments, as though all resulted from the policy. In fact government departments have contracted out to industry for years, to a greater or lesser degree.

*The Make-or-Buy Policy 1973-75 (Industry Branch, Ministry of State for Science and Technology; November 1975)
Onc diagram showing payments to Canadian industry for R\&D between 1963-64 and 1975-76 shows not only that research contracts have increased since the Make-or-Buy policy was initiated, but also that, years before, in 1965-66, such contracts were larger than any year until 1973-74, indicating that the grants level fluctuates from year to year, and that taking just a short-term view (that is, from 1973-76) can be misleading. (The year 1965-66 was a good one largely as a result of the hydrofoil project of the Department of Defense.)

Analysis of the figures used in the report actually shows that government R\&D contracts to industry had already begun to rise before the Make-or-Buy policy was put into effect, and, plotting them on a graph, that the level of R\&D contracts to industry would be at the same point they reached even if they had merely been extrapolated at their former rate.

Furthermore, the ratio of payments to industry vs. intramural $R \& D$ was less in 1975-76 than a decade earlier by a substantial margin (even though that was only for a single year). Even since the Make-or-Buy policy was introduced, the increase in industrial contracts has amounted to only roughly $\$ 20$ million, while the increase in in-

\section{Trudeau rings the changes}

Stung by the results of a public opinion poll that showed Canada's Liberal Government to be lagging far behind the opposition in popularity, and by criticisms of both his bilingualism and anti-inflation programmes, the Canadian Prime Minister, Pierre Trudeau, recently announced wide-ranging $\mathrm{C} \mathrm{a} \mathrm{b}$ in e $\mathrm{t}$ changes that have produced a new head for the Ministry of State for Science and Technology (MOSST).

Gone not just from the ministry, whose portfolio he held jointly with that of Public Works, but also from the government itself, is C. M. "Bud" Drury, who at 64 was one of the two most senior Cabinet members (with Mitchell Sharp, who has also resigned). In his place is Hugh Faulkner, a more junior minister who, according to the Toronto Globe and Mail's Ottawa correspondent, "was demoted from Secretary of State to Minister of State for Science and Technology mostly because the Liberal caucus felt that he had failed to sell bilingualism, a special responsibility of the Secretary of State." house research funds has amounted to $\$ 57$ million. And in terms of overall science expenditures by the federal government, industry's share has fallen from $19 \%$ to $16 \%$ during the threeyear period of the policy.

The report, which was only released this summer, admits that it is premature to assess whether the ultimate economic effect aimed for in the policy is yet being achieved. But it does claim that the policy has had a beneficial effect on several sectors of industry. At the same time, it admits that during the course of the past five years, the proportion of Canada's total resources directed at R\&D has steadily declined: gross national expenditure on research and development as a percentage of GNP had dropped in 1972 to $1.14 \%$ from $1.29 \%$ in 1969 , while the Senate special committee on science policy had said it should be about $2.5 \%$ to keep Canada competitive internationally.

The report finds that the effects of the policy to date have been most pronounced in electronics, transportation and scientific services, where objectives of government and industry most closely coincide in the context of current departmental missions. If the programme were to be extended-which the report thinks advisable-either a reduction in government scientific staff or a substantial increase in funds for contracts would be necessary.

Be that as it may, the new appointment is not calculated to cause rejoicing throughout the science community. Mr Faulkner's appointment makes it obvious that the science ministry will continue to be regarded by the government as a low priority, as it has been from its inception in 1971. Apart from $\mathrm{Mr}$ Drury, $\mathrm{Mr}$ Trudeau has always appointed inexperienced or junior ministers for this post.

The new appointment comes as just onc more disappointment for the science community. But to many, $\mathrm{Mr}$ Drury's attitude towards the needs of science in Canada had in recent months seemed apathetic if not openly hostile. In spite of studies and recommendations on national science organisation, the government in general and $\mathrm{Mr}$ Trudeau in particular apparently lost interest in science and technology. The concerns of bilingualism and inflation had loomed so large as to eclipse science, and doubts had grown about the government's professed concern for the problems of science-based industry. 